\title{
MORPHOLOGY AND SURFACE FEATURES OF DIAMONDS FROM THE JUÍNA KIMBELITE PROVINCE, BRAZIL
}

\author{
DÉBORA PASSOS DE ARAÚJO' ${ }^{1}$, JOSÉ CARLOS GASPAR ${ }^{1} \&$ LUIZ AUGUSTO BIZZI ${ }^{2}$
}

\begin{abstract}
RESUMO MORFOLOGIA E FEIÇÕES SUPERFICIAIS DE DIMANTES DA PROVÍNCIA KIMBERLÍTICA DE IUINAA, Brasil A morfologia e feições superficiais de duzentos e trinta e quatro diamantes primários e aluvionares da Província Kimberlítica de Juína, SW do Cráton Amazônico, foram investigados. As amostras são dos kimberlitos Juína-5, Collier-4 e SPM e dos aluviões Cinta Larga, São Luiz, Duas Barras e Porcão. Diamantes cinza, incolores e marrons predominam. As populações puderam ser diferenciadas de acordo com o grau de reabsorção. Todas as populações contêm pedras reabsorvidas e não reabsorvidas, entretanto, diamantes do kimberlito Juína- 5 são mais regulares e menos reabsorvidos enquanto diamantes dos kimberlitos Collier-4 e SPM e dos aluviões são mais reabsorvidos. Pedras não reabsorvidas são octaedros, que ocorrem como indivíduos simples, maclas e agregados. Cubos não foram identificados mas texturas cúbicas foram observadas em diversas pedras. Feições de corrosão octaédricas, cúbicas, tetrahexaedróide/dodecaédricas e irrestritas foram identificadas. A morfologia e texturas superficiais aqui reportadas e de trabalhos anteriores sugerem que os diamantes de Juína foram expostos à reabsorção no manto e no magma kimberlítico. Feições superficiais indicam que os diamantes foram submetidos a temperaturas moderadas a altas, fugacidade de oxigênio elevada e/ou longo tempo de reação. A alta proporção de pedras reabsorvidas dos kimberlitos Collier-4 e SPM, quando comparada ao kimberlito Juína-5, sugere que processos de reabsorção e corrosão após crescimento foram mais intensos nos dois primeiros magmas kimberlíticos.
\end{abstract}

Palavras-chave: diamante, Juína, morfologia, texturas superficiais, reabsorção, corrosão

\begin{abstract}
The morphology and surface textures of two hundred and four primary and alluvial diamonds from the Juína Kimberlite Province, SW of the Amazon Craton, were investigated. Samples are from the Juina-5, Collier-4, and SPM kimberlites, and from the rivers Cinta Larga, São Luiz, Duas Barras and Porcão. Dominant diamond body colors are gray, colorless and brown. Diamond populations investigated here could be distinguished according to the resorption degree. Even though non-resorbed and resorbed stones occur in all populations, the Juina-5 kimberlite contains the highest proportion of non-resorbed diamonds whilst resorbed stones are abundant amongst diamonds from the kimberlites Collier-4 and SPM. Non-resorbed diamonds are octahedral, occurring as single crystals, macles and aggregates. Cubes were not identified, although cubic textures were observed for numerous stones. Etching features indicative of octahedral, cubic, tetrahexahedroid/dodecahedral, and non-restricted surfaces were identified. Morphology and surface textures reported herein and from previous works imply that the Juína diamonds have been exposed to resorption in the mantle and in the kimberlitic magma. Surface features suggest that resorption and corrosion occurred under moderate to high temperature, elevated oxygen fugacity and/or long time of reaction. The higher proportion of resorbed stones for the Collier-4 and SPM kimberlites, compared to the Juína-5 Kimberlite, suggests that after-growth resorption and corrosion processes were more intense in the two first kimberlitic magmas.
\end{abstract}

Keywords: diamond, morphology, surface textures, resorption, corrosion

INTRODUCTION The primary morphology of diamonds may be modified through resorption and corrosion processes occurring throughout its residence in the mantle or during its extraction, in the transporting magma. Octahedral and cubic crystals may be converted to round-shaped diamonds (tetrahexahedroid and dodecahedra) together with the formation of etching figures. This transformation involves mass reduction and, presumably, small diamonds may be entirely eliminated. In order to understand such processes, diamond resorption and corrosion experiments have been carried out by several authors (e.g. Pandya \& Tolansky 1954 , Frank \& Puttick 1958, Patel \& Ramanathan 1962, Cull \& Meyer 1986, Arima \& Inoue 1995, Medelssohn \& Milledge 1995). Meanwhile, systematic description of diamond surface features have been proposed (e.g. Orlov 1997, Robinson 1980, Otter et al. 1991, MacCallum et al. 1991). Yet, the number of textures reproduced in laboratories is small when compared with the great variety of features observed in natural diamonds. This is probably caused by the very diverse nature of factors controlling resorption and corrosion events and the difficulty to reproduce multivariating conditions in the laboratory.

Deformation events occurring in the mantle are also registered in diamonds. Cracks and fractures are attributed to brittle deformation whilst glide planes, represented in diamond surfaces as lamination lines, are regarded as signs of plastic deformation.

This study comprises the morphological and surface texture description of 234 primary and alluvial diamonds from the Juína Province, NW Brazil. The Juína Province consists of twenty three known kimberlite intrusions and associated alluvial deposits. Gem-quality diamonds are rare and have only been reported from alluvial sites (Haralyi 1991).

GEOLOGICAL SETTING The Cretaceous Juína Province $\left(11^{\circ} 20^{\prime}-11^{\circ} 50^{\prime} \mathrm{S}\right.$ and $\left.58^{\circ} 45^{\prime}-59^{\circ} 25^{\prime} \mathrm{W}\right)$ is located at the southwestern border of the Amazon Craton. Most of the kimberlites intrude the northern border of the Parecis Palaeozoic basin and some isolated bodies occur in the Parecis' basement , the Mesoproterozoic sialic Rio Negro Juruena Mobile belt (1.8-1.5 Ga; Tassinari et al. 2000). The Province was discovered by the BRGM/De Beers joint venture through stream gravel regional survey. A U/Pb zircon emplacement age

I Instituto de Geociências - Universidade de Brasília. Brasília-DF, Brazil 70910-900. email: debora@ unb.br.

2 Companhia de Pesquisa e Recursos Minerais - CPRM, SGAN 603 Conjunto J Parte A $1^{\circ}$ Andar - Brasília-DF, Brazil. 70830-030. 
of 92-95 Ma obtained from a volcanoclastic kimberlite breccia (Heaman et al. 1998) is in agreement with palinologic studies in the crater sediments, which indicates an age of 93,5 Ma (Teixeira et al. 1998a). A Rb/Sr age of $198 \mathrm{Ma}$, though, is reported by Bizzi (1983). The Juína Province is emplaced along the megalineament AZ 125, which controls a number of ultramafic alkaline provinces in Brazil, such as Alto Paranaíba, Paranatinga and Poxoréu (Gonzaga \& Tompkins 1991). Locally, a strong NE tectonic system controlled the emplacement of the kimberlite pipes (Teixeira et al. 1998b).

The intrusions in the Rio Negro - Juruena Mesoproterozoic terrains occur between the basins of the Vinte e Um de Abril and Cinta Larga Rivers. Kimberlite pipes are deeply weathered (Haralyi 1990) and do not show striking surface features (Teixeira et al. 1998a).

The study of xenoliths suggests that the lithosphere beneath the Rio Negro-Juruena Belt was mainly constituted by Iherzolite and eclogite and that the Juína diamonds should not be associated with a depleted harzburgite Archean keel (Teixeira et al. 1998b). This is reinforced by $\mathrm{Sm} / \mathrm{Nd}$ data (Sato and Tassinari 1997) that points to juvenile material accretion from 2.2 to $1.7 \mathrm{Ga}$.

The kimberlite structures are suggested to be the result of a series of explosions producing a complex pile of pyroclastic fall and surge deposits (lapillistone and crystal tuff kimberlite), interbedded with resedimented volcanoclastic kimberlite (Teixeira et al. 1998a). The classic diatremes and large craters are absent. Kimberlite craters are large (up to 55 ha), rounded shaped and shallow (20 to $80 \mathrm{~m}$ ).

PREVIOUS WORKS Diamonds have been described in the local river basins and in two ancient high-level paleochannels. The latter have their source in the local kimberlite intrusions (Haralyi 1990, Gaspar et al. 1998) and are considered as the diamond source for part of the current alluvial deposits (in particular, the Cinta Larga basin; Haralyi 1990).

Inclusion-bearing diamonds from the São Luiz River (Cinta Larga basin) have been extensively discussed in the literature after the finding of high pressure assemblages related to the transition zone and the lower mantle (Wilding et al. 1991, Harte \& Harris 1994, Hutchison 1997, Hutchison et al. 1999, Kaminsky et al. 2001). The morphology and surface features of primary and alluvial diamonds from this region is reported in this paper. Hutchison (1997) investigated 61 diamonds from the São Luiz River. They exhibit octahedral, dodecahedral, and irregular or macle morphologies. Cubic forms are absent and dodecahedral stones are more common than octahedral. Evidence of plastic deformation (lamination lines) and resorption (surface pitting or etching features such as trigons and stepped morphology) were found in all diamonds. Colorless and, mostly, brown diamonds are dominant in samples from São Luiz. Yellow stones were not found. Brittle deformation was observed in a significant proportion of São Luiz diamonds $(55 \%)$, particularly those suggested to have derived from the lower mantle (Hutchison et al. 1999).

Gaspar et al. (1998) studied macrodiamonds from the Juína kimberlites and alluvial deposits. These stones are mostly dodecahedral to irregularly-shaped but octahedral, aggregate and macle also occur. Brown and light-brown colors dominate, although white, milky, yellow, and pink diamonds are also reported. Diamonds are inclusion-rich and commonly etched (frost, striation, dissolution lamellae, roll relief, trigons, and pits).

Kaminsky et al. (2001) investigated 475 diamonds from the São Luiz, Mutum, Rio Vermelho, and Córrego Chicora drainages. Diamonds are mostly dodecahedroids (55-70\%), and irregular (approximately one third of the total sample). Octahedral (about 5\%) and combined forms (4 - 7.5\%) are minor. Shagreen texture was described as the only microrelief texture found in dodecahedroid diamonds. Crystals are commonly pale, almost colorless, but dark brown, and semitransparent stones with a silky luster have also been reported. Plastic deformation bands and etching channels are abundant.

METHODS Primary and alluvial diamond samples studied here were provided by Rio Tinto Mineração Ltd and De Beers Brasil. Primary diamonds are from the kimberlites Juína-5 (50 stones), Collier-4 (100 stones), and SPM (38 stones). Alluvial diamonds are from the rivers São Luiz (10 stones), Duas Barras ( 8 stones), Porcão ( 8 stones) and Cinta Larga (20 stones).

Diamond morphology was first described under binocular microscope (up to $50 \mathrm{x}$ magnification) at the University of Brasília. Backscatter electron images were taken of 40 stones selected from the Juína-5, Collier-4, and SPM kimberlites at the Technology Mineral Center (Cetem, Rio de Janeiro) using a SEM LEO S440 $(20 \mathrm{kV}, 75$ to $150 \mathrm{pA}$, working distance of $25 \mathrm{~mm}$ and magnification from 65 to 10,000 times).

Selected diamonds were manually polished to reach inclusions. Microprobe EDS analyses (Cameca SX50) of inclusions were performed at the Geosciences Institute, University of Brasília.

Diamond crystallizes as octahedral, cubes, and cubeoctahedral, which may be transformed by resorption process to dodecahedra ( 12 rhombic faces), tetrahexahedroid ( 24 triangular faces; more common) or combined forms of octahedral with tetrahexahedroid/dodecahedra. The term tetrahexahedroid was first suggested by Robinson (1980) to designate crystals showing tetraexaedral symmetry. The resorption of diamonds is classified according to Robinson (in MacCallum et al. 1989) in six categories (Figure 1). Their preservation degree is estimated using Robinson's criteria. Category 1 comprises resorbed stones (tetrahexahedroid or dodecahedra) with 1 to $55 \%$ mass preservation. Category 6 represents non-resorbed octahedral crystals and slightly resorbed stones (up to $1 \%$ of mass loss). Categories 5 to 2 are combined forms showing respectively $95 \%, 85 \%, 75 \%$, and $62.5 \%$ mass preservation, as illustrated in Figure 1.

The diamond description scheme adopted here is that listed in Table I (based on Robinson 1980 and Otter et al. 1994). Dodecahedral crystals are characterized by a three-fold symmetry axis $\left(E_{3}\right)$ relating the rhombic faces. The term tetrahexahedroid is used when a six-fold axis occurs instead and the rhombic faces of the dodecahedron are divided in the middle (by the "c" edge) yielding a 24-faced tetrahexahedroid form. Rounded dodecahedra are referred to as category I resorbed crystals whenever the crystallographic elements could not be recognized. Combined forms are referred to as octahedron-tetrahexahedroid, octahedron-dodecahedron, and octahedron-rounded dodecahedron. The degree of resorption is defined according to the above mentioned categories. Macles and aggregates are also discriminated. Corrosion features have been associated to octahedron, cube, tetrahexahedroid/ dodecahedron, and non-restricted surfaces, as devised by 


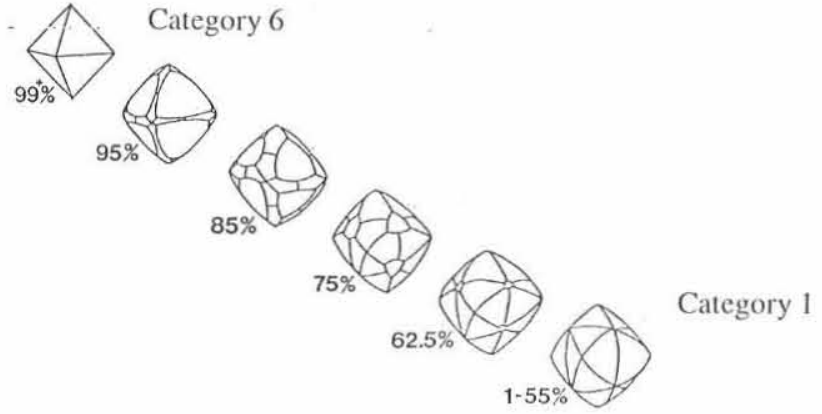

Figure I - Sequence of conversion of an octahedron (category 6) to a tetrahexaedroid (Category 1) Percentages are the preservation degrees in each category (Robinson in MacCallum et al. 1989).

Robinson (1980).

JUÍNA DIAMOND CHARACTERISTICS Diamonds are described below according to their color, transparency, regularity, size, primary morphology, deformation, resorption and corrosion features. Some diamond characteristics are markedly more abundant in some populations but the limited number of specimens did not allow for robust confident limits. Table 1 illustrates the optical and morphological characteristics of the Juína Province diamonds, and the approximate distribution of such features. Most of the Juína Province stones are fragments $(>59 \%)$, but their characteristics could still be satisfactorily described.

Fine-grained discrete and planar opaque inclusions are very common in the diamonds of the province.

Color and transparency Diamond color was not a distinguishing feature among populations (Table 1), as both primary and alluvial diamonds are mainly gray, followed in abundance by colorless and brown types. Yellow, white, and pink stones also occur. The studied stones are mostly transparent, but translucent varieties were also recognized. Opaque crystals are rare (Table 1).

Regularity The samples were described as regular, distorted, flat, and elongated diamonds. Samples that could not be assigned to any of these classes had their regularity referred to as unknown (Table 1).

Diamond regularity differs between populations. Primary diamonds from the Juína- 5 kimberlite are mostly regular (42\%; Figure 2A), with a minor proportion of flat and elongated individuals. Diamonds with unknown regularity are abundant in samples from the kimberlites Collier-4 and SPM ( 50\%). Regular, flat, distorted (Figure 2C), and elongated stones are nearly equally distributed in the Collier-4 kimberlite, as is also the case for elongated (Figure 2E) and regular diamonds in the SPM kimberlite. Alluvial diamonds are mainly distorted $(34 \%)$, followed by stones with unknown regularity, regular, and flat.

Primary morphology The size of unbroken stones varies from 1.0 to $1.6 \mathrm{~mm}$ while fragments range from 1.2 to $4.0 \mathrm{~mm}$. All studied diamonds with primary morphology preserved are octahedral crystals. They occur both as macles (considered here just as twinning planes parallel to (111), e.g. Figure $3 \mathrm{~A}$ ) and aggregates (figures $2 \mathrm{~A}, 3 \mathrm{C}$, and $4 \mathrm{E}$ ). Cubes were not found but cubic textures were observed for numerous stones. Octahedra are abundant in the Juína-5 kimberlite (42\%) but rare in the Collier-4 and in the SPM kimberlites as well as in alluvial stones. Amongst the octahedral diamonds from the Juína-5 kimberlite, approximately $70 \%$ are macles (Fig. 3A), $17 \%$ are single stones and $13 \%$ are aggregates (Fig. 2A). Unknown morphology was ascribed to some of the diamonds (up to $22 \%$ for the alluvial stones).

Macles are common amongst diamonds from the Juína-5 kimberlite $(46 \%)$ but were also described in the Collier-4 kimberlite (16\%), the SPM kimberlite (5\%) and alluvial diamonds $(15 \%)$. Twinning planes not related to (111) were recorded for most of the studied diamonds (50 to 60\%). Aggregate crystals are 5 to $11 \%$.

Deformation features Diamonds are usually fractured suggesting that they were affected by brittle deformation processes. Corroded breakage surfaces (Table 1) indicate fracturing prior to corrosion by the transporting magma. Therefore, some breakage may take place in the magma.

Lamination lines, which are the surface manifestation of plastic deformation, are observed in part of the Juína diamonds (Table 1; Figure 2E). The usual relationship of brown diamonds with plastic deformation was not observed here.

Lamination lines were described on primary and alluvial diamonds. The populations with a higher percentage of resorbed diamonds (Collier-4 and SPM kimberlites and alluvial diamonds) tend to present a greater percentage of stones with lamination lines, up to $40 \%$. The Juina-5 diamonds, which are mostly octahedra, show this feature in up to $18 \%$ of the stones. This is in accordance with observations made by Robinson (1980) who suggested that lamination lines are more prominent in tetrahexahedroid/dodecahedral surfaces.

Resorption features Except for the Juína-5 diamonds, category 1 tetrahexahedroid/dodecahedral stones are dominant in the Juína Province. The SPM kimberlite diamonds were classified mostly as tetrahexahedroid (63\%; Figs. 2E and 2F) and rounded dodecahedra (category 1). Such forms also predominate in the Collier-4 kimberlite population (55\%; Figs. $3 \mathrm{E}$ and $4 \mathrm{~A}$ ) and among the alluvial stones (56\%). Combined forms (category 2 to category 5) and octahedra are not abundant in the Collier-4 kimberlite (14\% and $11 \%)$, in the SPM kimberlites $(8 \%$ and $3 \%$ ) or in the alluvial diamonds $(4 \%$ and $15 \%)$.

The Juína-5 kimberlite population differs from all others, since octahedral are the more abundant type (42\%; Fig. 2A), followed by combined forms (30\%; Fig. 3D), tetrahexahedroid (6\%; Fig. 3C) and dodecahedra (8\%).

The observation of three- and six-fold symmetry axes in single crystals is not rare in the population analyzed. This feature could be related to the difference in resorption rates for single crystals and aggregates.

Corrosion features Etching figures may be useful to unravel diamond morphology. Surface textures related to octahedral, cubic, tetrahexahedroid/dodecahedral, and non-restrict surfaces (Robinson 1980) are listed in Table 1.

In diamonds from the Juína-5 kimberlite, trigons (Figure 3D) are the most common octahedral feature (54\%). This is in agreement with their dominant octahedral morphology. 
Table I - Summary of morphology and surface textures of primary and alluvial diamonds from the Juina Kimberlite Province

\begin{tabular}{|c|c|c|c|c|c|}
\hline 1. Diamond form & & $\begin{array}{c}\text { Collier-4 } \\
\text { Kimberlite } \\
\% \\
\end{array}$ & \begin{tabular}{|c|} 
Juína-5 \\
kimberlite \\
$\%$ \\
\end{tabular} & $\begin{array}{c}\text { SPM } \\
\text { kimberlite } \\
\%\end{array}$ & $\begin{array}{c}\begin{array}{c}\text { Alluvium } \\
\text { deposit } \\
\%\end{array} \\
\end{array}$ \\
\hline \multirow{5}{*}{ Regularity } & Regular & 18 & 42 & 21 & 20 \\
\hline & Distorted & 10 & 0 & 0 & 34 \\
\hline & Flat & 13 & 26 & 3 & 10 \\
\hline & Elongated & 11 & 6 & 26 & 5 \\
\hline & Unknown & 49 & 26 & 50 & 29 \\
\hline \multirow[t]{8}{*}{ Morphology } & Octahedral & 11 & 42 & 3 & 15 \\
\hline & Octahedral-tetraexahedroid & 9 & 10 & 5 & 2 \\
\hline & Octahedral-dodecahedral & 1 & 2 & 0 & 0 \\
\hline & Rounded octahedral-dodecahedral & 4 & 18 & 3 & 2 \\
\hline & Tetraexahedroid & 36 & 6 & 63 & 51 \\
\hline & Dodecahedral & 5 & 0 & 3 & 0 \\
\hline & Rounded dodecahedral & 13 & 8 & 13 & 5 \\
\hline & Unknown & 21 & 14 & 11 & 22 \\
\hline \multirow{3}{*}{ Intergrowth } & Macle (//111) & 16 & 46 & 5 & 15 \\
\hline & Twin plane & 59 & 56 & 58 & 51 \\
\hline & Aggregate & 11 & 10 & 5 & 10 \\
\hline \multirow[t]{7}{*}{ Resorption } & Category 1 & 55 & 14 & 76 & 63 \\
\hline & Category 2 & 1 & 0 & 0 & 0 \\
\hline & Category 3 & 2 & 6 & 3 & 0 \\
\hline & Category 4 & 4 & 12 & 5 & 2 \\
\hline & Category 5 & 8 & 12 & 0 & 2 \\
\hline & Category 6 & 9 & 42 & 3 & 15 \\
\hline & Unknown & 21 & 14 & 13 & 15 \\
\hline \multirow{3}{*}{ Crystal state } & Unbroken & 26 & 26 & 32 & 27 \\
\hline & Fragment & 74 & 72 & 66 & 59 \\
\hline & Unknown & 0 & 0 & 3 & 12 \\
\hline \multicolumn{6}{|l|}{ 2. Body color } \\
\hline \multirow[t]{3}{*}{ Transparency } & Transparent & 77 & 82 & 53 & 63 \\
\hline & Transluscent & 22 & 18 & 47 & 24 \\
\hline & Opaque & 3 & 0 & 0 & 10 \\
\hline \multirow[t]{9}{*}{ Color } & Colorless & 25 & 36 & 8 & 5 \\
\hline & Light gray & 33 & 50 & 61 & 59 \\
\hline & Dark gray & 2 & 0 & 0 & 0 \\
\hline & Yellow & 5 & 8 & 5 & 2 \\
\hline & Light brown & 12 & 2 & 5 & 15 \\
\hline & Brown & 18 & 4 & 21 & 2 \\
\hline & White & 8 & 6 & 3 & 22 \\
\hline & Amber & 1 & 0 & 0 & 0 \\
\hline & Pink & 2 & 0 & 0 & 2 \\
\hline \multicolumn{6}{|l|}{ 3. Inclusions } \\
\hline \multirow{5}{*}{ Transparent } & White & 2 & 0 & 5 & 0 \\
\hline & Red & 15 & 8 & 0 & 0 \\
\hline & Orange & 6 & 8 & 0 & 2 \\
\hline & Green & 9 & 0 & 0 & 0 \\
\hline & Brown & 2 & 12 & 0 & 5 \\
\hline \multirow[t]{2}{*}{ Opaque } & Discrete & 77 & 78 & 63 & 46 \\
\hline & In fracture planes & 2 & 2 & 53 & 10 \\
\hline
\end{tabular}


Table I (cont.) - Summary of morphology and surface textures of primary and alluvial diamonds from the Juina Kimberlite Province

\begin{tabular}{|c|c|c|c|c|c|}
\hline \multicolumn{2}{|l|}{ 4. Surface textures } & \multirow{2}{*}{$\begin{array}{c}\text { Collier-4 } \\
\text { Kimberlite } \\
\% \\
\end{array}$} & \multirow{2}{*}{$\begin{array}{c}\text { Juína-5 } \\
\text { kimberlite } \\
\%\end{array}$} & \multirow{2}{*}{\begin{tabular}{|c|} 
SPM \\
kimberlite \\
$\%$ \\
\end{tabular}} & \multirow{2}{*}{$\begin{array}{c}\text { Alluvium } \\
\text { deposit } \\
\% \\
\end{array}$} \\
\hline \multirow{11}{*}{ Octahedral } & Planar surfaces & & & & \\
\hline & Triangular plates & 7 & 4 & 0 & 10 \\
\hline & Lamination & 20 & 42 & 3 & 10 \\
\hline & Non-oriented triangular pits & 52 & 30 & 55 & 24 \\
\hline & Trigons & 24 & 54 & 8 & 12 \\
\hline & Sub-hexagonal depressions & 12 & 0 & 11 & 5 \\
\hline & Hexagons & 3 & 4 & 3 & 10 \\
\hline & Hexagons including triangular pits & 5 & 0 & 0 & 5 \\
\hline & Serrated lamination & 9 & 16 & 5 & 7 \\
\hline & Positively oriented triangular pits & 0 & 0 & 0 & 0 \\
\hline & Stratification lines & 60 & 58 & 21 & 7 \\
\hline \multirow{4}{*}{ Cubic } & Non-oriented tetragonal pits & 31 & 12 & 34 & 17 \\
\hline & Crescent steps & 7 & 0 & 0 & 0 \\
\hline & Pointed plates & 0 & 0 & 3 & 2 \\
\hline & Stratification lines & 5 & 0 & 21 & 2 \\
\hline \multirow{9}{*}{$\begin{array}{l}\text { Dodecahedral/ } \\
\text { tetraexahedroid }\end{array}$} & Terraces & 0 & 0 & 0 & 0 \\
\hline & Hillocks & 26 & 0 & 8 & 0 \\
\hline & Elongated hillocks & 14 & 14 & 39 & 12 \\
\hline & Pyramidal hillocks & 11 & 0 & 11 & 7 \\
\hline & Fine hillocks & 12 & 10 & 24 & 17 \\
\hline & Shagreen & 87 & 54 & 89 & 76 \\
\hline & Corrosion sculpture & 1 & 0 & 3 & 0 \\
\hline & Shallow depression & 3 & 2 & 0 & 5 \\
\hline & Stried & 0 & 0 & 3 & 0 \\
\hline \multirow{13}{*}{ Non-restricted } & Lamination lines & 39 & 18 & 34 & 34 \\
\hline & Stratification lines & 1 & 2 & 47 & 5 \\
\hline & Ruts & 7 & 18 & 5 & 10 \\
\hline & Etch channel & 16 & 0 & 34 & 7 \\
\hline & Network pattern & 0 & 0 & 0 & 0 \\
\hline & Inclusion cavity & 46 & 48 & 34 & 10 \\
\hline & Knob-like asperities & 1 & 2 & 0 & 0 \\
\hline & Discs & 1 & 0 & 0 & 0 \\
\hline & Frosting & 7 & 12 & 0 & 2 \\
\hline & Marks & 0 & 0 & 3 & 0 \\
\hline & Fractures & 7 & 4 & 0 & 2 \\
\hline & Corroded cleavage surface & 43 & 38 & 24 & 5 \\
\hline & Non-corroded cleavage surface & 21 & 28 & 18 & 22 \\
\hline \multicolumn{2}{|c|}{ 5. average dimension $(\mathrm{mm})$} & 2,20 & 1,78 & 1,94 & 2,66 \\
\hline
\end{tabular}

Lamination, triangular pits, serrated lamination (figures $3 \mathrm{~A}$ and $3 \mathrm{~B}$ ) and triangular plates are also common, whilst hexagons are rare. Non-oriented trigonal pits (usually in cleavage surfaces) are found in diamonds from the SPM (55\%) and Collier-4 kimberlites ( $52 \%)$, and from the alluvial deposits (24\%). Lamination, trigons, serrated lamination, hexagons, and triangular plates were also observed. Trigons (negatively oriented relative to the (111) face), triangular pits (nonoriented), lamination, serrated lamination, and hexagons all represent octahedral etching.

Cubic etching features described for the Juína Province diamonds are tetragonal pits (non-oriented), and rare crescent steps and pointed plates. Crescent steps (figures $3 \mathrm{E}$ and $3 \mathrm{~F}$ ) were only observed among the Collier-4 diamonds and pointed plates were described for the SPM kimberlite and alluvial deposits. As observed by Robinson (1980), crescent steps are always associated with tetragonal pits. The TR2-15 sample from the Collier-4 kimberlite presents notable tetragonal features. Deep and long etching channels have their walls covered by tetragonal pits (Fig. 4B). The stone is a resorbed aggregate (Fig. 4A), probably originally comprised of cubic crystals. Details of the tetragonal pits are shown in figures $4 \mathrm{C}$ and 4D. Pyramidal and flat pits have been observed and there are pits with less than $1 \mu \mathrm{m}$, which are formed at the surface and at the flat base of the large pit (Fig. 4D). Growth lines are observed in the inclined wall of the pit (Fig. 4D). Tetragonal pits are not abundant but were identified in all populations (Table 1).

Most of the Juína diamonds are covered by the shagreen texture. Robinson (1980) suggested this term in allusion to the 

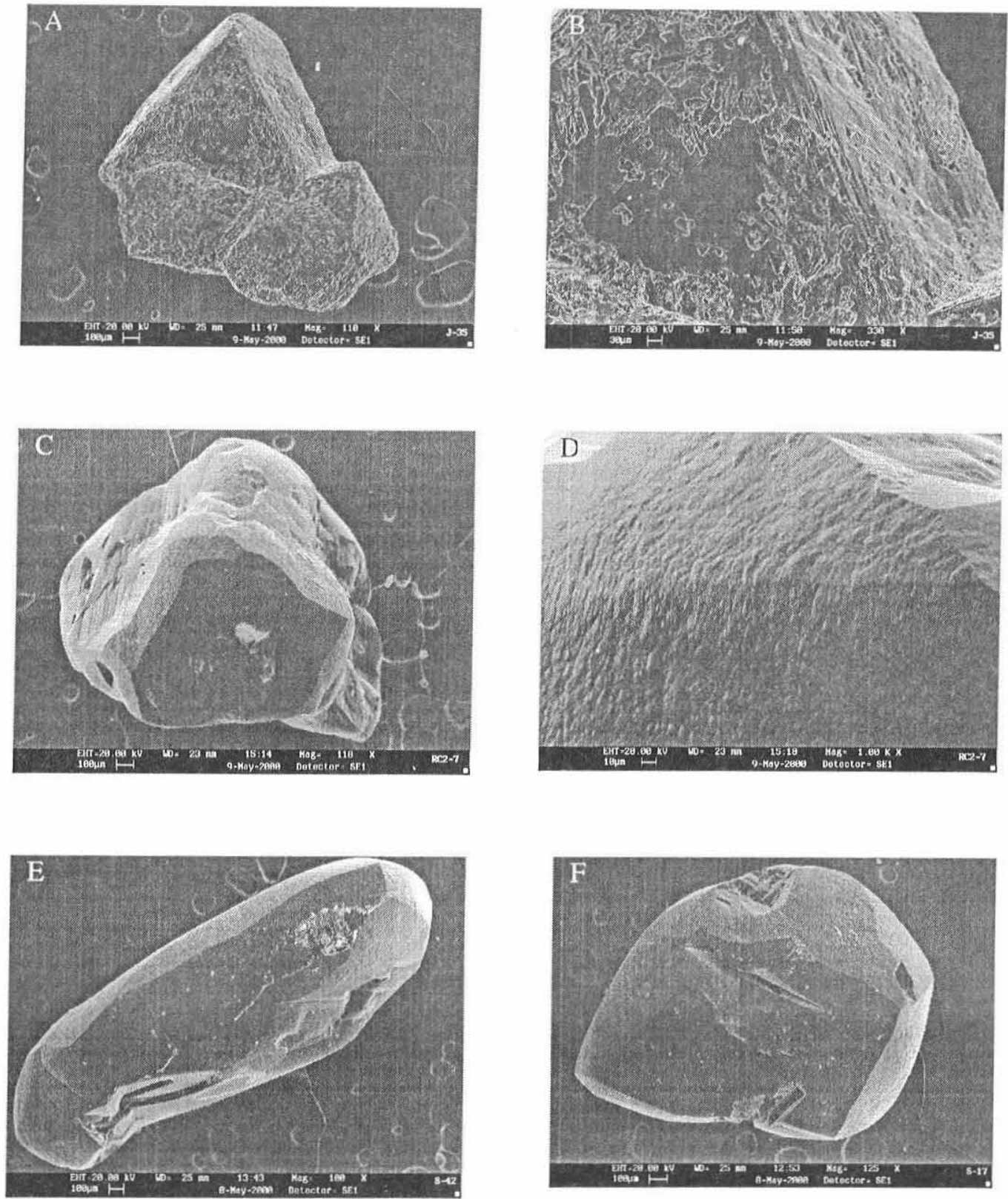

Figure 2 - Morphology and surface features of diamonds from the Juína Province. A) Sample J-36 (Juína 5 kimberlite) Corroded (frosting) aggregate of octahedral crystals. Category 6. B) Detail of Figure 2.A. Corrosion of octahedral surfaces and formation of trigons. C) Sample RC2-7 (Collier-4 kimberlite) - Fragment of aggregate of tetrahexaedroid crystals. Category 1.D) Detail of Figure 2.C. Shagreen texture in resorbed surface.E) Sample S42 (SPM kimberlite) - Elongated tetrahexaedroid ("rice grain") exhibiting shagreen texture and lamination lines (left side of the crystal, near the corner). Category I.F) Sample SI7 (SPM kimberlite) - Flat tetrahexaedroid displaying shagreen texture and etching channel. Tetragonal pits are observed in the upper part of the stone. Category 1.

rough surface of shark's skin. The shagreen texture was described for more than $75 \%$ of the diamonds, except for the Juína- 5 population, in which $54 \%$ of the stones exhibit this texture. Hillocks are also common in the Collier-4 (Fig. 4F) and SPM kimberlites, and in alluvial diamonds, but are minor among the Juína-5 stones. Less frequent textures are corrosion sculptures occurring in diamonds from the SPM kimberlite, shallow depressions (Fig. 4A) in stones of the Collier-4 and SPM kimberlites and alluvial deposits, and striation found in diamonds from the SPM kimberlite.
Non-restricted textures such as inclusion cavities, frosting (Figs. 2A, 2B, and 4E), etching channels (Figs. 2F and 4A), ruts, asperities, dises, and impact marks were described (Table 1). Frosting was mainly detected on octahedral stones and etching channels were only described for diamonds from SPM and Collier kimberlites and from alluvial deposits. Partially corroded stones were described for samples from the Collier Kimberlite (Fig. 4E).

DISCUSSION Diamonds can be corroded and resorbed in 

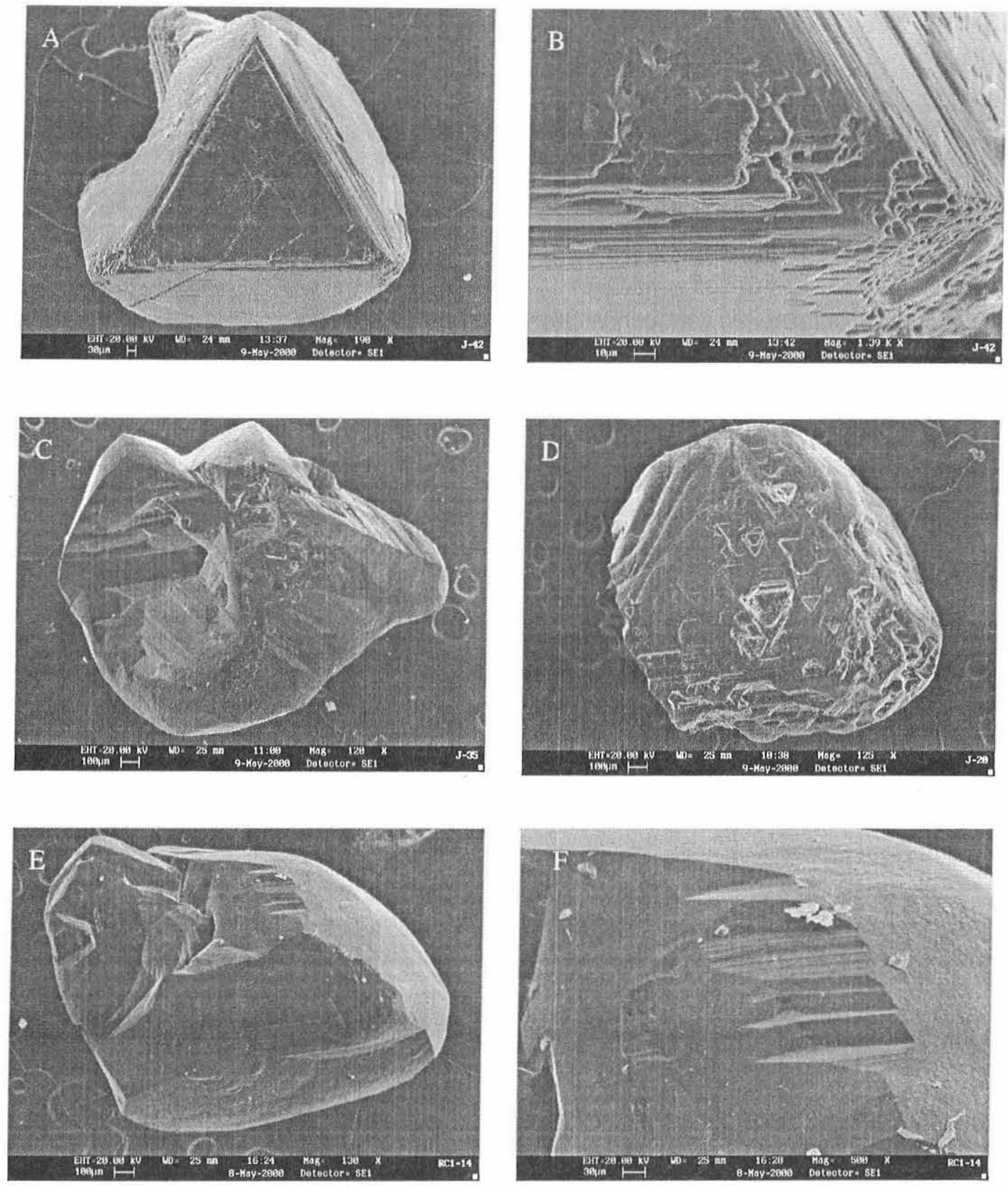

Figure 3 - Morphology and surface features of diamonds from the Juina Province.A) Sample J42 (Juina-5 kimberlite) - Macle of octahedra displaying lamination and serrated lamination. Category 6. B) Detail of Figure 3.A. Magnification of serrated lamination in the corner of the macle. C) Sample J35 (Juina kimberlite) - Fragment of aggregate crystals of tetrahexaedroid. Resorbed surfaces show shagreen texture and hillocks. Category 1. D) Sample J20 (Juína-5 kimberlite) - Fragment of octahedron-rounded dodecahedron. Trigons occur in the (III) surface and shagreen texture is observed in minor resorbed surfaces. Category 4. E) Sample RCI-14 (Collier-4 kimberlite) - Distorted tetrahexaedroid showing inclusion cavity (left), etching channel (left-center) and tetragonal textures. Category 1. F) Detail of Figure 3.E. Crescent steps and tetragonal pits are observed.

the mantle and/or in the transporting magma. In order to understand the secondary morphology and etching figures produced in such processes, corrosion and resorption experiments have been performed by several authors (e.g. Evans \& Sauter 1961, Patel \& Ramanathan 1962, Kanda et al. 1977, Cull \& Meyer 1986, Arima \& Inoue 1995, Medelssohn \& Milledge 1995). The experiment of Kanda et al. (1977) demonstrated that etching pits start forming before the resorption of edges and corners takes place. Also, pyramidal pits give place to flat pits as the process evolves. The formation of specific textures could be related to temperature, under nonoxidizing conditions, where positively oriented pits are formed under lower temperature than negative ones (e.g. Evans \& Sauter 1961, Harris \& Vance 1974, Medelssohn \& Milledge 1995). Evans and Sauter (1961), for example, formed positive triangular pits bellow $900^{\circ} \mathrm{C}$ and trigons above $1000^{\circ} \mathrm{C}$. 

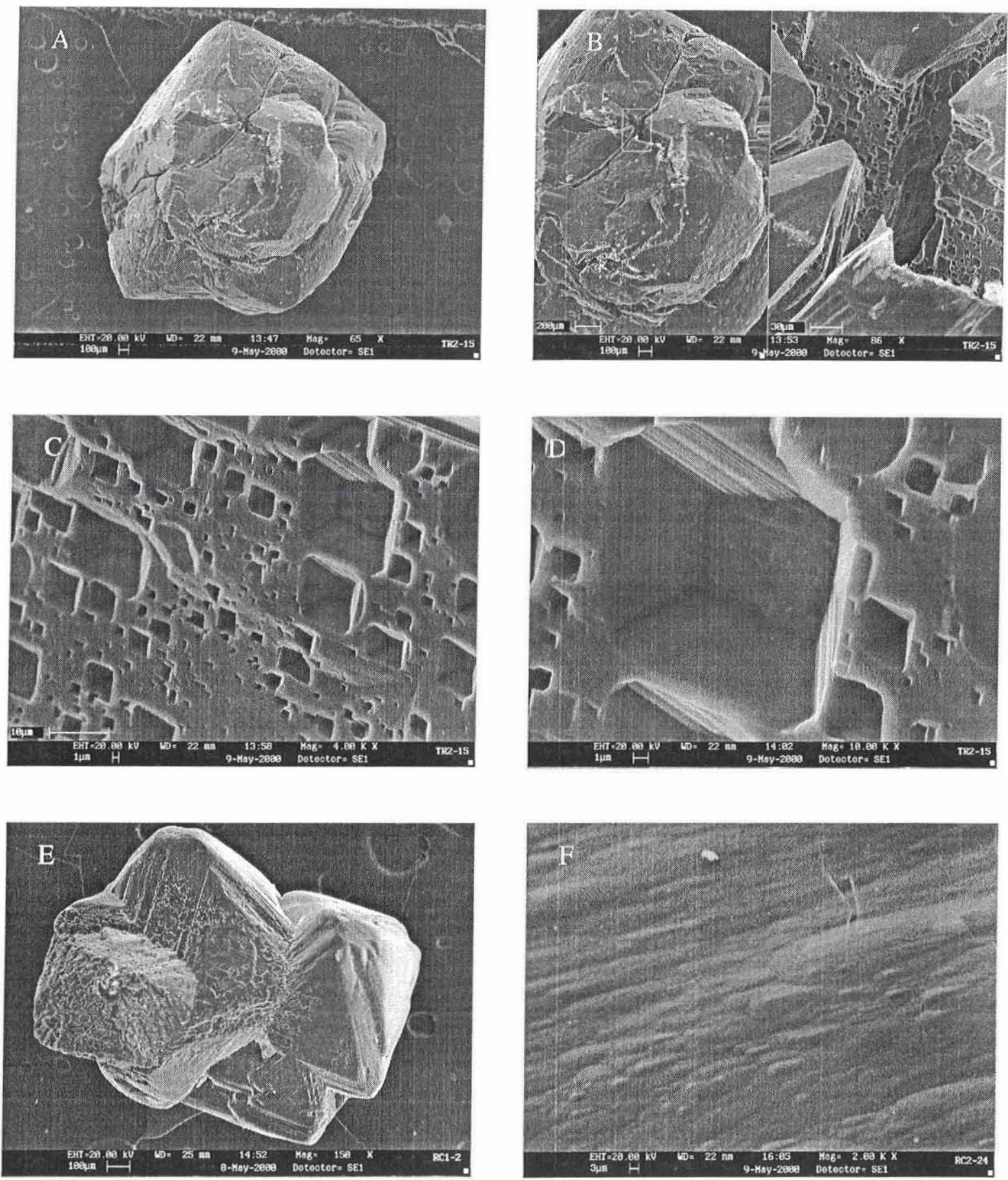

Figure 4-Morphology and surface features of diamonds from the Juina Province. A) Sample TR2-15 (Collier-4 kimberlite) Aggregate of tetrahexaedroid crystals intensely corroded. Long etching channels and shallow depressions (upper right) are observed. Category 1.-B) Detail of Figure 4.A. The walls of the etching channels are corroded displaying myriads of tetragonal pits. C) Detail of Figure 4.B. Pyramidal and flat tetragonal pits. D) Detail of Figure 4.C. Formation of new tetragonal pits in the flat base of the large pit. Growth lines are observed in the inclined wall. Tetragonal pits may be smaller than 1?m. E) Sample RCI-2 (Collier-4 kimberlite) - Aggregate of regular octahedral displaying stepped layering with rounded edges, lamination, trigons, serrated lamination and frosting. Corrosion is more prominent in the left side of the aggregate. Category 6. F) Sample RC2-24 - Magnified view of fine and elongated hillocks in the resorbed surface of a fragment.

Hexagons were observed for intermediate temperatures. Other factors controlling diamond corrosion and resorption are time of reaction, oxygen fugacity (e.g. Patel \& Ramanathan 1962,
Cull \& Meyer 1986, Medelssohn \& Milledge 1995), and carbon concentration (Arima \& Inoue 1995). Cull \& Meyer (1986) reacted diamond with a $\mathrm{CO}-\mathrm{CO}_{2}$ gas mixture con- 
trolling temperature, time of reaction and $\mathrm{fO}_{2}$. Although the increment of temperature and time of reaction favored corrosion and resorption, the most influential factor controlling these processes was the oxidation state of the reaction, where highest $\mathrm{fO}_{2}$ values were more corrosive. Low carbon concentration also contributes to diamond resorption and corrosion (Arima \& Inoue 1995).

As pointed above, variation of oxygen fugacity, temperature, pressure, or carbon concentration may affect resorption of diamonds. In addition, resorption occurring in the transporting magma depends on factors such as i) the depth in which the diamond is released from the xenolith and enters in contact with the magma; ii) the corrosion/resorption potential of the magma; and iii) the original size of diamonds, since smaller crystals have greater surface to volume ratios and are consumed faster than bigger ones (Robinson et al. 1989). The first parameter will influence the time of reaction. The second depends on temperature, pressure, carbon concentration and oxidation state of the magma. All these factors are able to control resorption separately, though oxygen fugacity is the most influential one (Arima \& Inoue 1995).

Primary diamonds from the Juína Province (this study) could be distinguished on the basis of their morphology and surface features. The Juína-5 kimberlite diamonds are mostly octahedral stones and combined forms. Octahedral textures predominate and highly-resorbed category I diamonds also occur. Non-resorbed stones presenting pits are in accordance with experimental data and indicate that pits are formed prior to resorption. Surface textures of these diamonds indicate highly variable degree of resorption and corrosion.

Conversely, occurrence of resorbed stones (mostly category 1) accompanied by textures such as shagreen, hillocks, pits, ruts, corrosion sculptures, shallow depressions, and etching channels, are evidence of the advanced degree of resorption of the diamonds from the Collier-4 and SPM kimberlites and from the alluvial deposits.

Diamonds studied here were also examined for nitrogen content (Araújo et al. 2001, this volume and Araújo 2002). $82 \%$ of the population is type II while type I diamonds are highly aggregated and present low nitrogen content (usually up to $300 \mathrm{ppm}$ ). There does not seem to exist any relation between $\mathrm{N}$ content and morphology of the Juína diamonds, the implication being that one could not possibly correlate less resorbed stones with source depth or chemistry. Considering the variable conditions that the Juína diamonds presumably have been exposed to and the lack of information on such conditions, the relation of surface textures to mantle residence and transporting conditions becomes speculative. The highly resorbed nature of part of the diamonds, the absence of low temperature textures as positively oriented pits, and the rare occurrence of intermediate temperature textures as hexagons and frosting suggest that the Juína diamonds could have been exposed to i) moderate to high temperature ii) elevated oxygen fugacity and/or iii) long time of reaction.

Diamonds from São Luiz investigated by Hutchison (1997) and Kaminsky et al. (2001), allegedly related to the transition zone and upper part of the lower mantle, are type II stones (Nfree) or type I diamonds mostly containing low nitrogen. That is in agreement with observations that diamonds from the lower mantle and transition zone described worldwide are mostly nitrogen free (e.g. Deines et al. 1991, Stachel \& Harris 1997, Hutchison 1997, Davies et al. 1999, MacDade \& Harris
1999). Besides the unusual assemblage of mineral inclusions of the São Luiz diamonds (Hutchison 1997), features suggestive of deep origin for them are the irregular morphologies, brown coloration, deformation, occurrence of platelets in plastically deformed stones and complex history of growth (Hutchison $e t$ al. 1999).

Evidence of complex history of crystallization, resorption, plastic deformation and brecciation in the Juína diamonds were presented by Gaspar et al. (1998), who suggested a combination of intermittent stages of crystallization, resorption, and shearing to produce this diamond population. The authors also attribute the low gem quality of the stones to the complex history of formation they have gone through.

SUMMARY AND CONCLUSIONS Primary and alluvial diamonds from the Juína Kimberlite Province, emplaced in Mesoproterozoic terrains in the southwestern border of Amazon Craton, NW Brazil, have been investigated. Diamonds were described according to their color, transparency, regularity, size, primary morphology, deformation, resorption and corrosion features. Four diamond populations from the Juina-5, Collier-4, and SPM kimberlites, and from alluvial deposits were described.

Diamond populations were not distinguished according to their color. They are mostly gray, colorless and brown, followed by yellow, white, and pink stones. The Juina- 5 kimberlite contains the highest proportion of regular diamonds whilst unknown regularity is abundant amongst stones from the kimberlites Collier-4 and SPM. Distorted diamonds dominate in the alluvial deposits.

Non-resorbed diamonds are octahedral, occurring as single crystals, macles and aggregates. Cubes were not identified, although cubic textures were observed for numerous stones. Resorbed samples were referred to as tetrahexahedroid/ dodecahedra and combined forms. Etching features indicative of octahedral, cubic, tetrahexahedroid/dodecahedral, and nonrestricted surfaces were identified.

The Juina-5 kimberlite population comprises regular octahedral diamonds, combined forms and minor tetrahexahedroid/dodecahedra. Octahedral stones present etching figures such as trigon, lamination, non-oriented triangular pits, and serrated lamination.

The Collier-4 and SPM kimberlites populations and diamonds from the alluvial deposits are mostly resorbed stones showing abundant tetrahexahedroid/dodecahedral surface features such as shagreen texture followed by hillocks, corrosion sculptures, shallow depressions, and striation. Octahedral diamonds are less abundant. The observed octahedral etching features were non-oriented trigonal pits (usually in cleavage surfaces), lamination, trigons, serrated lamination, hexagons, and triangular plates. These populations also present the majority part of cubic etching features herein described as tetragonal pits (non-oriented), crescentic steps, and pointed plates.

Non-restricted textures such as inclusion cavities, frosting, etching channels, ruts, asperities, discs, and impact marks were described. Frosting was mainly detected on octahedral diamonds and etching channels were only described for diamonds from SPM and Collier kimberlites and from alluvial deposits. Evidence of brittle and plastic deformation, respectively fracturing and lamination lines, were found.

$\mathrm{N}$-free diamonds dominate among the samples studied here 
(Araújo et al. 2001, Araújo 2002), which is in agreement with prior results for Juína diamonds assigned to the lower mantle and transition zone (Hutchison 1997, Kaminsky et al. 2001). Cathodoluminescence revealed that intermittent growth and resorption events occurred during the growth of Juína diamonds (Hutchison 1997, Gaspar et al. 1998, Araújo 2002).

Morphology and surface textures reported herein and from previous works imply that the Juína diamonds could have been exposed to resorption in many situations, such as in the deep mantle, during ascent within a mantle plume, at the base of the lithosphere, and finally, in the kimberlitic magma. Surface features suggest that resorption and corrosion occurred under moderate to high temperature, elevated oxygen fugacity and/or long time of reaction. Assuming diamond resorption was an important process during ascent in the kimberlitic magma, the higher proportion of resorbed stones for the Collier-4 and SPM kimberlites may suggest a distinct resorption character for these liquids when compared to the Juína-5 Kimberlite.

Acknowledgements The authors wish to thank RTDM and De Beers Brasil for providing the samples. We greatly acknowledge the valuable assistance of Dr. Arnaldo Alcover (Cetem, RJ) with the SEM images, and of MSc. Simone Gióia (UnB) for sample preparation. To the reviewers of RBG for suggestions to the manuscript.

\section{Referências}

Araúijo D.P. 2001. Mineralogia dos Diamantes da Província Kimberlítica de Juína, MT. Tese de doutorado Universidade de Brasília, Brasília.

Araúijo D.P., Gaspar J.C., Frei Y., Hauri E.H., Hemley R. 2001. Mineralogy of diamonds from the Juína kimberlite province, SW Amazon Craton, Brazil: cathodoluminescence, infrared spectroscopy, nitrogen content, and carbon and nitrogen isotopes. (This volume).

Arima M. \& Inoue M. 1995. High pressure experimental study on growth and resorption of diamond in kimberlite melt. In: IKC, International Kimberlite Conference, 7. Extended Abstracts. p.8-10

Bizzi L.A. 1993. Mesozoic alkaline volcanism and mantle evolution of the southwestern São Francisco Craton, Brazil. Tese de Doutorado. Cidade do Cabo, África do Sul.

Cull F.A. \& Meyer H.O.A. 1986. Oxidation of diamond at high temperature and $1 \mathrm{~atm}$ total pressure with controlled oxygen fugacity. In: IKC, International Kimberlite Conference, 6. Extended Abstracts. p. 377-379

Davies R.M., Griffin W.L., Pearson N.J., Andrew A.S., Doyle B.J., O'Reilly S.Y. 1999. Diamonds from the deep: Pipe DO-27, Slave Craton, Canada. In: J.J. Gurney, J.L. Gurney, M.D. Pascoe, S.H. Richardson (eds.), IKC, International Kimberlite Conference, 7, Proceedings, 1:148-155

Deines P., Harris J.W. \& Gurney, J.J. 1991. The carbon isotopic composition and nitrogen content of lithospheric and asthenospheric diamonds from the Jagersfontein and Koffiefontein kimberlite, South Africa. Geochim. Cosmoch. Acta, 55:2615-2625

Evans T. \& Sauter D.H. 1961. Ecthing of diamond surface with gases. Phil. Mag, 6:429-440

Frank F.C.\& Puttick K.E. 1958. Ecth pits and trigons on diamond: II. Phil. Mag, 3:1273-1279

Gaspar J.C., Teixeira N.A., Steele I.M. 1998. Cathodoluminescence of Juína Diamonds. In: IKC, International Kimberlite Conference, 7. Extended Abstracts. p.242-244

Gonzaga G.M. \& Tompkins, L.A. 1991. Geologia do Diamante. In: Principais Depósitos Minerais do Brasil. Vol. IVA. 461pp.

Haralyi N.L.E. 1990. Os diamantes de Juína, Mato Grosso. In: Principais Depósitos Minerais do Brasil, Vol. IV, Parte A. DNPM/CPRM.: 155-160

Harris J.W. e Vance E.R. 1974. Studies of the reaction between diamond and heated kimberlite. Contrib. Mineral. Petrol., 47:237-244.

Harte B. \& Harris J.W. 1994. Lower mantle mineral associations preserved in diamonds. Mineral. Mag, 58A:384-385

Heaman L., Teixeira N.A., Gobbo L., Gaspar J.C. 1998. U-Pb zircon ages for kimberlites from the Juína and Paranatinga provinces, Brazil.. VII Conf. Int. Kimberlitos, Resumos expandidos, pp.:322-324.

Helmberger D.V., Wen L., Ding, X. 1998. Seismic evidence that the source of the Iceland hotspot lies at the core-mantle boundary. Nature, 396:251-255

Hutchison M.T. 1997. Constitution of the deep transition zone and lower mantle shown by diamonds and their inclusions. Ph.D. Thesis. Edinburgh, UK

Hutchison M.T., Cartiny P., Harris J.W. 1999. Carbon and nitrogen compositions and physical characteristics of transition zone and lower mantle diamonds from São Luiz, Brazil. In: J.J. Gurney, J.L. Gurney, M.D. Pascoe, S.H.
Richardson (eds.), IKC, International Kimberlite Conference, 7, Proceedings, p.372-382

Kanda H., Yamaoka S. \& Setaka N. 1977. Etching of diamond octahedrons by high pressure water. J. Crystal Growth, 38:1-7

Medelssohn M.J. \& Milledge H.J. 1995. Morphological characteristics of diamond populations in relation to temperature-dependent growth and dissolution rates. Int. Geol. Rev, 37:285-312

Orlov Yu. L. 1977. Morphology of Diamond Crystal. In John Wiley \& Sons (eds.) The mineralogy of the Diamond.:59-106

Otter M.L., McCallum M.E., Gurney J.J. 1994. A physical characterization of the Sloan (Colorado) diamonds using a comprehensive diamond description scheme. In: H.O.A. Meyer \& O.H.Leonardos (eds.), IKC, International Kimberlite Conference, 5. Diamonds: Characterization, Genesis, and Exploration, Proceedings, CPRM Special Publication 1B Jan/94. p.15-31

Pandya D.C. \& Tolansky S. 1954. The etching of diamond. II. Cleavage, dodecahedron and cube faces. Proc. R. Soc., A225:40-48

Patel A.R. \& Ramamnathan S. 1962. Etch pits on diamond surfaces. Phil. Mag., $7: 1305-1314$

Robinson D.N. 1980. Surface Textures and other Features of Diamonds. Ph.D. Thesis. Natal, S.A. 221 p.

Robinson D.N., Scott J.A., van Niekerk A., Anderson V.G. 1989. The sequences of events reflected in the diamonds of some Southern African kimberlites. In: IKC, International Kimberlite Conference, 5, Proceedings. Kimberlites and Related Rocks. V2. Their Mantle/Crust Setting Diamonds and Diamond Exploration. p. 990-1000.

Sato K. \& Tassinari C.C.G. 1997. Principais eventos de acreção continental no Cráton Amazônico baseados em idades modelo Sm-Nd, calculada em evoluções de estágio único e estágio duplo. In: Contribuições à Geologia da Amazônia.:91-141

Stachel T. \& Harris J.W. 1997. Syngenetic inclusions in diamonds from the Birim field (Ghana) - a deep peridotitic profile with a history of depletion and reenrichment. Contrib. Mineral. Petrol., 127:336-352

Tassinari C.C.G., Bettencourt J.S., Geraldes M.C., Macambira M.J.B., Lafon J.M. 2000. The Amazonian Craton. In: Tectonic Evolution of South America. (ed. U.G. Cordani, E.J. Milani, A. Thomaz Filho, D.A. Campos) p.41-95

Teixeira N.A., Gaspar J.C., Oliveira A.L.A.M., Bitencourt R.M. \& Yeda B. 1998a. Morphology of the Juina Maars. In: IKC, International Kimberlite Conference, 7. Extended Abstracts. p.902-904

Teixeira N.A., Gaspar J.C., Waissel O., Almeida A.J., Belther J.A. \& Gobbo, L. 1998b. Geology of the Juína Diamondiferous Province. In: IKC, International Kimberlite Conference, 7. Extended Abstracts. p.905-907

Wilding M.C., Harte, B. \& Harris J.W. 1991. Evidence for a deep origin for São Luiz diamonds. In: IKC, International Kimberlite Conference, 5. Extended Abstracts. p. $456-4.58$

Manuscrito A-1313

Recebido em 02 de dezembro de 2001 Revisão dos autores em 22 de dezembro de 2001 Revisão aceita em 23 de dezembro de 2001 